Nordicom Review 29 (2008) 1, pp. 133-144

\title{
Downcast Eyes
}

\author{
Michael Haneke and the Cinema of Intrusion
}

\author{
AsbJøRn GrønStad
}

\begin{abstract}
In Austrian director Michael Haneke's Caché (2005), the specter of the culturally repressed returns in the form of mute, unrelenting images that seem to demand something of the protagonists in the film. This article argues that Caché, in its troubled but timely reflection on the enigmatic images that make up our shared visual culture, negotiates an ethical space within the film-world in which the audience is confronted not only with historical events that they would rather forget but also with their own complicity in the more contemporary injustices of which the subaltern is victim. With a view toward understanding the complex rhetoric of the film's images of confrontation, the article suggests that the director's iconoclastic project derives much of its psychological and emotional force from the narrative deployment of the figure of intrusion.
\end{abstract}

Keywords: Haneke, politics of intrusion, transgression, politics of looking, visual ethics, postcolonialism

\section{Introduction}

The intense clarity of the image failed to satisfy us, for it seemed to hide as much as it revealed; and while it seemed to invite us to pierce the veil and examine the mystery behind it, its luminous concreteness nevertheless held the eye entranced and kept it from probing deeper

Friedrich Nietzsche

The feared dizziness of vision may be precisely its monstrous and intimidating silence

Régis Debray

'I thought you should be here to see this.'

In the age of globalization and frenzied visuality, the battle over the possession of history no less than that over representation itself often takes the form of a contest of images. When rendered invisible, odious historical truths can sometimes be elided and laid to rest. The unearthing and re-visualization of deliberately suppressed events is obviously a key task for historical scholarship especially within postcolonial studies, but occasionally this subject is broached also by artists, writers and filmmakers. In this article, I shall examine how the Austrian director Michael Haneke (b. 1942) re-imagines and problematizes a long forgotten scandal in French postwar history - the massacre of Algerians in Paris in 1961 - and how he brings his viewers face to face with the enduring 
ramifications of this black chapter in the narrative of the nation. My focus will be on the ways in which Caché implicates the viewer in the events described by the film and also on the withholding or even obliteration of cinematic pleasure that Haneke's games entail. The filmmaker's iconoclastic project, I argue, revisits the figure of intrusion so prevalent in some of his earlier films like Funny Games (1997) and Code Unknown (2000) and aligns his work with a counter-cinema tradition whose antecedents include the likes of Luis Buñuel, Jean-Luc Godard, Laura Mulvey and Chantal Akerman.

If there is a contemporary filmmaker whose work appears to be premised upon the rigorously entrenched modernist legacy of negative poetics, it must be Haneke. ${ }^{2} \mathrm{~A}$ film critic and television director turned filmmaker, Haneke gained instant notoriety with his second feature, Benny's Video (1992) and has since become known as one of European cinema's most respected auteurs, winning the prestigious Grand Prize for The Piano Teacher at the 2001 Cannes Film Festival. Resolutely anti-Hollywood and obsessed with the representation of violence in the mass media, Haneke has self-consciously adopted the catharsis theory as a kind of meta-psychological framework for a cinema which, by his own admission (Haneke 1992: 89), aims to "unsettle the viewer" and "take away any consolation" (Sharrett 2004). His films might in fact seem to be essentially about the punishing and victimization of the audience. His overall project, as some critics have pointed out, appears to be the reinvestment of shock-value in the image (Wheatley 2006: 34). Cinematic assaults on the viewer like Funny Games (1997) - in which the terrorization of the bourgeois family evidently is meant to be taken as the metaphorical projection of the position of the audience into the diegesis of the film - would appear to consolidate this perception of the director as someone who is determined to let the brutalization of the spectator be the guiding principle of his art. Regrettably, however, the pigeonholing of Haneke's cinema in terms of an updated Aristotelianism and an ideology of controversy - in no small measure abetted by the director's own ruminations - has tended to eclipse the moral and philosophical density of his films. In short, the almost manifesto-like and ultimately too crude description of the hanekesque has come infelicitously to interfere with an awareness of the films themselves. Disastrously, and - in the case of Haneke - ironically, media reputation has overshadowed the complex arguments of the individual films; the image has been mistaken for its substance (a major concern for Haneke, as we shall later see), thus obfuscating a number of pivotal issues which underlie and deepen the rhetoric of the films in question. It is not uncommon for imagemakers (and particularly those of the politically and aesthetically controversial ilk) to be better rallyists than artists, but Haneke is too accomplished a film artist to ever become the successful didacticist he seemingly aspires to be.

Haneke can certainly be seen as a descendant of rather illustrious intellectual forebears - Eisenstein and his cine-fist (1998) (the Austrian once remarked that he wished to "slap" his audience in the face; Sharrett 2004), Adorno and his critique of the culture industry (1972), Debord and his indictment of late capitalist visuality (1967), and finally, Godard and his relentless interrogation of the epistemologies of the image - but maybe not in the way that most critics imagine. It would be unfortunate to read Haneke's films as visual enunciations of a reactionary, knee-jerk existential pessimism or as an incongruous, confused condemnation of our present media-saturated society. Haneke is neither Ulrich Seidl nor Oliver Stone. His poetics of negation is not limited to a denunciation of mainstream cinema or the intimidation of the viewer; it easily surpasses the occasionally facile rhetoric of his own extra-textual statements. But the images he creates do make us uncomfortable, though not in the same way that Gaspar Noé's or Lars von 
Trier's images make us uncomfortable. Where the labor of the transgressive in the latter appears to leap out from a disordered and largely unmanageable visual world that is yet all too clearly the projection of a deliberately iconoclastic artistic imagination, in Haneke it seems that it is visuality itself that has become transgressive. In an unprecedented way, the image in Caché has acquired a sense of human volition, and that is perhaps the most unspeakable transgression of all.

\section{The Problem of (what) the Image (wants)}

Framed by two disturbing stationary shots of an urban street and a school building respectively, the densely textured Caché is ostensibly a narrative about cultural guilt and individual responsibility in the context of the aftermath of French postcolonialism. Central to the unfolding of the film's drama is the motif of the return of the repressed, the physical manifestation of which is a succession of videocassettes containing a deeply disconcerting recording of the house of the main protagonists, a bourgeoisie couple played by Daniel Auteuil and Juliette Binoche. Caché, like most of the director's previous efforts, seems intent on victimizing the viewer by provoking a sense of constant anxiety and imminent dread, which derive not so much from the diegetic actions depicted as from the oppressive ubiquity of a visual regime with an inexhaustible capacity for deception and manipulation. The film's opening shot chillingly projects an image of the gaze itself, the act of looking as a morally alert and probing gesture which demands something of the viewer. This discourse on the indeterminate status of the image which Caché invites, is indicative of an underlying and more profound epistemological concern discernible in all of Haneke's films. But in Caché, the problem of the authenticity, readability and communicability of the image is further augmented by a growing suspicion that the optical ecology within which the characters are immersed is not only amorphous but even anthropomorphic. All the different types of mediated images that proliferate in this universe - the enigmatic footage on the surveillance tapes; the grotesque, childlike drawings that accompany the cassettes; the television news reports from Iraq and Palestine; the images from his childhood that the Auteuil character dreams in his sleep; the telephoto shot of his son's school which concludes the film - behave as if they were animated beings with drives, desires, and demands of their own. Preposterous as it may seem, this conception of the image as a living organism - explored at length in a recent book by W.J.T. Mitchell (2005) - may offer a renewed hermeneutic framework within which to grasp the increasingly ambivalent and precarious relation between the viewing subject and the unknowable visual codes that surround her.

The unflinching gaze which so ominously requests something from the viewer - and which may even seem accusatory and capable of instilling guilt - is itself an emburdened image. In its deafening silence, it is still expected to incarnate and transmit a sense of the representational immensity of historical injustices that the culture has suppressed. With T.J. Clark, one might say that the images in Caché have been called upon "to do too much work - to stand for an ethics and politics" that can be stated "only by means of them" (2006: 43). If the cinematic image is not a representation but an event, as Steven Shaviro has suggested (1993: 24), it is at the same time an event which sometimes conceals other and more subterranean events even as it is prompted by them. The subtextual secret at the center of Caché is the massacre that took place in Paris on October 17 1961, a national tragedy that seemed to have been erased from cultural memory virtually overnight. Protesting a racist curfew that the Parisian chief of police Maurice 
Papon had recently introduced, ${ }^{3}$ thousands of Algerians took to the streets that day to participate in a peaceful demonstration promoted by the National Liberation Front. More than 7,000 policemen managed to stifle the protests by blocking access to the city, in the process opening fire on the crowds and throwing victims into the Seine. While the police at the time claimed that only two Algerians had been killed in the turmoil, historians have estimated that up to 200 people were murdered. Astoundingly, the event received very little media coverage, possibly to due to political censorship in France and biased reporting abroad. Only in 1998 did the French government acknowledge that the massacre had in fact occurred, and in 2001 a plaque was unveiled near the Saint Michel bridge to commemorate the victims. Questions of responsibility and guilt, however, were not addressed.

Haneke originally conceived Caché as a collaborative project with actor Daniel Auteuil, based on an idea in which someone is confronted with their own guilt. ${ }^{4}$ In an interview included in the dvd version of Caché, the director tells us that he only became aware of the events of October 1961 after watching a documentary about the Algerian War on the German-French television network ARTE. Making this publicly silenced incident the understated pivot of his film, Haneke attempts in Caché to allegorize the collective culpability for the massacre through an exploration of the psychology of guilt as it affects the film's principal protagonist. Georges Laurent, played by the taciturn Auteuil, is the host of a popular television program about literature. As a little boy, we gradually learn, he was responsible for the ejection of his adopted Algerian brother from the family, a selfish act motivated by an unsavory mixture of jealousy and fear. This act of betrayal has not been on the adult Georges's mind in a long time, but he is forced to revisit it when he starts to suspect that Majid, his long forgotten childhood brother, may be the shadowy source of a succession of vaguely threatening videotapes that he and his wife have received. In the movies, as David Lynch's Lost Highway (1997) has already established, the arrival of anonymous recordings of your house is an ill omen.

\section{Showing Seeing}

From its very first shot, Caché identifies the chasm between seeing and perception as a fundamental predicament of that hypervisual culture that has been so astutely dissected in previous Haneke films such as Benny's Video, Funny Games and, above all, Code Unknown. The unswerving interest in this rupture, which is on the whole epistemological in nature, is yet another example in the director's work of a close thematic affinity with a particular fixation whose provenance is undeniably modernist. ${ }^{5}$ This is how the film begins: an immobile camera stares impassively though forebodingly at the entrance of the Laurent home in a long, uninterrupted take, until we start to hear the low murmur of voices on the soundtrack and the image abruptly starts to rewind. As it turns out, the shot is not the real time recording of the façade of the house from the street, but rather the playback of that recording on a VCR located inside the same house which features on the tape. In terms of point of view, we are not just watching a static image of the house; we are watching the Laurents watch that same image. Narratively speaking, an additional level of mediation - adding another perspective - has intervened in the framing of the shot. The film thus instantly propels us into the tense subjectivity of the protagonists, who are watching themselves being watched by an unidentified and possibly hostile observer who discloses very little, if any, information about himself or the context for his act of surveillance. Haneke's opening shot, which effectively creates a claus- 
trophobic, somber mood for the narrative that ensues (not only are we confronted with an inscrutable and encroaching gaze but we are also thrust into the consciousness of the victims of that gaze), is in a sense a pure figuration of that meta-perceptual act that Mitchell has named "showing seeing" (2002). An image is always the product of a process of seeing, and it always shows us something - its spatial determination, an object, material forms - but this process itself is more often than not hidden from view. Showing seeing is different from showing what the act of seeing shows. Nor is showing seeing reducible to an image of the process of seeing. ${ }^{6}$ Neither the look nor the object (or their relationality) is constitutive of the kind of metaperceptualism implied in Mitchell's phrase. While each instance of seeing is part of a frenetically heterogeneous, infinite multiplicity of discrete acts of looking, showing seeing entails that phenomenon capable of picturing these separate acts while remaining outside their totality. Showing seeing involves the wresting of specificity from the act of seeing.

From a theoretical vantage point, it is of course feasible to imagine a mechanism that in turn shows the process of showing seeing, and so on, so that the whole relation becomes a visual equivalent of sorts of the Derridean notion of deferral. This, however, is not the point. What matters here is that the opening shot of Caché compellingly approximates a condition which enables the performance of seeing. Lingering onscreen for $2 \frac{1}{2}$ minutes before its eerie tranquility is interrupted by the voices of the Laurents, the transfixed view of their abode comes across as nothing less than the mediation of a lacuna. "Well," says Georges, as the first word uttered in the film. "Nothing," his wife replies, referring to the image we have just seen. Then the camera cuts to a shot of the couple leaving the house to locate exactly where the camera might have been placed. Upon their re-entering the house, Haneke cuts back to the previous view, which soon begins to fast-forward. The tape, we are told, goes on in the same manner for two hours. Not much happens. We see pedestrians crossing the street, automobiles driving by, people on bicycles and motorbikes. What the camera captures is, in essence, the quotidian rhythms of Parisian street life in the morning hours. The appearance of this footage in the couple's home raises a number of questions for which the subsequent narrative fails to provide adequate answers. Who is the tape from? What does it mean? What is the purpose of its existence?

Less explicit but equally salient is the divergent nature of the range of suggestions which the image engenders. The shot, first of all, appears empty, despite the presence of a hodgepodge of urban architectural elements - structures, buildings, traffic, vegetation - cluttering the frame. Second, the camera seems fairly unassuming or even inert, like any surveillance device, yet it simultaneously evokes a menacing vibe. An image devoid of presence, it nonetheless insinuates something present off screen. And third, by refusing to move as much as an inch away from this delineated space, the shot gives the viewer a perhaps stronger sense of temporality than of spatiality, so that what Haneke in effect shows us is an image of time passing. Lastly, the perspectival source of the image is overdetermined, collapsing as it does two different points of view into one hybrid subjectivity.

\section{The 'Here' and the 'Elsewhere:' Humanism under siege}

Haneke's films often features trespassers and intruders and the quintessential Haneke image is one of intrusion. Poised between the thematic twin poles of the invasion-of-privacy narrative and the criticism of the media, the director's films straddle what are, indisputably, towering social issues in early $21^{\text {st }}$ century culture. In Caché, as in Funny Games, 
Haneke re-appropriates the generic template of the domestic invasion story, epitomized by Sam Peckinpah's harrowing Straw Dogs (1971), and - in the case of the former - turns it inside out. The house and those who inhabit it have become the culprits in Caché; the intruders are not a gang of drunken ruffians, as in Straw Dogs, but people who are themselves victims. The home is no longer a sanctuary but a place of pent-up animosity and frightful secrets. And, most significantly, Caché redefines the scope of the story by transforming what was, for Peckinpah, an examination of the psychology of masculinity under siege into a meditation on the vulnerability of the Western European consciousness when exposed to its own complicity in the affliction of the culturally dispossessed. Haneke thus collectivizes this supposedly most private and apolitical of genres, which revolves around the microcosm of the victimized family and the galvanization of the vigilant father-warrior. It is no longer about the family but the ideologies which produce it, the political economy of bourgeois culture. The disturbance in the Laurent household cannot be contained, or even properly identified, because it belongs to the realm of the unconscious and the everyday, not the tangible and the exceptional.

Hence, the real drama of Caché goes on behind the scenes, as it were. Where most of the director's fellow cine-provocateurs rely for their act of transgression upon the performance of on/scenity, to invoke Linda Williams's term (2004: 3), Haneke buries it among the uncommunicative pixels of his unyielding video image. The film is not so much about the depth of the object as about the depth of looking itself. What is most terrible is that which is off-screen, that which cannot be shown or visualized on account of its psychic banishment, its cultural silencing. Caché is an apposite title for a film which strives to elucidate the logic of that nexus where the problems of the image and visuality, repression, and memory interlock. Derived from the Vulgar Latin coacticare ("store up", "collect", "compress"), again derived from the Latin coactare ("constrain") and from coactus (past participle of cogere, "collect"), caché comprises the meanings of both "hidden" and "concealed." In English, the word cache can mean either a hiding place, something hidden in a cache, or a computer memory from which data that is regularly used can be swiftly retrieved. The word is also homonymic with cachet, prestige. Connotationally speaking, the title of Haneke's film resonates with all these meanings, converging upon a semantic space where memory itself has become the hiding place for that which the gaze of intrusion desires.

Caché fever, then, is the name of the game in Haneke's ethically animated universe of unwavering glances and downcast eyes. His film allegorizes the moral paralysis of a society besieged by the specter of crimes history has omitted. As a filmic gesture, this allegory contains a double movement, as it not only foregrounds the return of the culturally repressed but also introduces, however obliquely, the themes of immigration, nationhood, discrimination and the globalization of labor in postcolonial Europe. Released domestically mere weeks before the most pervasive social unrest France had seen since the May 1968 riots, Caché and its delineation of fearful cultural asymmetries could be taken both as an inauspicious harbinger of this conflagration and as its condensed backstory, its symptom. The film that the reviewers of Sight and Sound voted best movie of 2006 (James 2007: 32) would also seem to be the one most closely attuned to the social turmoil simmering beneath the pan-national veneer of the ever expanding European Union. But the ideologically seditious nature of Caché reaches far beyond its serendipitous topicality.

The unmentionable transgression at the cold heart of Haneke's film is the bracketing and denaturalization not only of the lebenswelt of the European bourgeois but of the 
normally incontestable repertoire of humanist values that this world encapsulates. Accomplished mostly on the level of mise-en-scéne and framing, this unaffected critique of Eurocentrism nullifies that aesthetic contract forged by Enlightenment thinkers and conceived as a way of regulating the relationship between artistic production, cultural subjectivity and regimes of power. Haneke's critical agenda not only in Caché but in several of his older films - certainly The Piano Teacher - in part resembles the deconstructive project intriguingly attempted by Clyde R. Taylor in his book The Mask of Art, in which he de-universalizes and re-historicizes the notion of Aesthetics and its purchase on Euro-humanism. "The way aesthetic philosophy was constructed as a cog in a developing concept of humanity", he writes, "while that humanity was endorsed in only one geographical and 'racial' population, has influenced all the available notions of social uplift through the arts" (Taylor 1998: 290). The painstaking aestheticization of everyday life and domesticity represents for the Laurent family the real fortification against all the unpleasantness of the outside world. The walls of the living room are adorned by magnificent bookshelves, which look imposing vis-à-vis the television set from which emanates the latest news stories from ongoing conflicts in the Middle East and other remote spaces. One could be led to believe that Haneke here quotes Godard and Anne-Marie Miéville's film essay Ici et ailleurs (Here and Elsewhere, 1974), which both contrasts and conjoins images of the "here" of the domestic life of a French family watching television with images of the "elsewhere" of the Palestinian Liberation Organization. The political thrust of Caché is the dramatization of the ways in which the "here" and the "elsewhere" inescapably interrelate.

Enclosed by all the towering literature, the presence of the Laurents' television set seems negligible and trivial, its testimony drowned out by the gravity and sheer intellectual heaviness of the bibliophile space. In a home like this, the atrocities from the broadcast are as much of an intruder as the mysterious videotapes themselves. But the ameliorative middle class humanism which the books connote offers a welcome respite from the barbarism of global events, cheapened as they are in this particular environment by their association with the unrefined medium of television. The vigor of the film's rhetoric lies not so much in its severe disclosure of the smugness of the cultured elite but rather in its implication that Western European humanist ideals and aesthetics are in cahoots when it comes to bolstering cultural privileges at the expense of the disenfranchised postcolonial subject. The state of marginalization in which the subaltern finds himself is even inscribed on a formal level in Caché, in that the silence and invisibility of the subject responsible for the tapes become a foil to his lack of discursive representation in the culture at large.

\section{Haneke's Negative Aesthetics}

What makes Caché a politically transgressive film is that, in the same breath, it obdurately suggests that the Laurents' complacency is a mere mirror image of that of the spectator. Archaic notions of viewer identification do not apply to Haneke's a-psychological form of cinema. As the filmmaker himself has affirmed, he deliberately endeavors to eschew characterization in favor of something he defines as "projection surfaces for the sensibilities of the viewer" (Sharrett 2004). And the visual aloofness of the director's style, so frequently noted by critics and viewers alike, is nothing if not illustrative of the glacialization of our sensibilities as viewers, our decreasing ability to be shocked by images; the coldness of Haneke's style becomes an exteriorization of 
what Fredric Jameson once called the "waning of affect" (1991: 16). Unlike many other contemporary filmmakers who seem to aim for the destruction of cinematic pleasure, the Haneke of Caché does not make us cringe by showing nauseating images of violence (a single grueling scene notwithstanding) or by portraying sexual behavior deemed deviant by the mainstream. Caché violates the viewers' sensibilities not by immersing them in the hideous matter of alterity, in everything which contradicts their own values and experience - in the abject, in short - but rather by rubbing their noses in the moral insufficiency of their own politics. In this, Haneke may have committed the definitive transgression: the moral indictment of current humanist culture and the denunciation of an aesthetic tradition to which the film itself so demonstratively belongs. Such a grand project may appear unrealizable, for how can we trust the philosophy of a film the enunciation of which is contingent upon an aesthetics invalidated by it? Doesn't this rhetorical conundrum seem like an impasse? Not if we can appreciate the difference between aesthetics and aestheticism, and not if we can accept the notion that aesthetic objects should be considered and appraised at least as much as purveyors of theoretical thinking and ideas as unadulterated works of art. The purity and impenetrability of the artistic realm is precisely the illusion that Haneke seeks to explode in his renegade films. The various tropes of intrusion, infringement, disturbance and invasion that recur throughout his later oeuvre in particular are emblematic of this disregard for the ideologically untouchable insularity of entelechical Euro-aesthetics. The social pertinence of the contemporary art object as well as its epistemological legitimacy, Haneke seems to say, is locatable in the work's potential for transcending its own aesthetic autonomy. One way to accomplish this would be to project the desire for the disruption of cinematic pleasure onto the level of film form. Caché, for instance, is not just a narrative about intrusion; the film itself enacts an intrusion upon the subjectivity of the viewer.

The signifiers of aesthetic affluence in the Auteuil/Binoche residence - what Christopher Sharrett calls "the bourgeois appropriation and administration of the entirety of Western culture" (Sharrett 2005: 61) - do not only represent a cultural fortress protecting the sanctity of humanist values from the corrosive influence of the vulgar mass media and of disagreeable events in faraway places. But perhaps equally important, the Laurent library is at the same time also a tremendous pretense; more than anything, the bookshelves are a form of embellishment and interior design. In George's studio, the books that decorate the room are even fake. That the social environment of this film would be that of the façade is clearly hinted at from the very outset - after all, in the opening sequence the camera lingers on the exterior of the Laurent home for several minutes. From this accentuation of the surface of things another sense of caché emerges. In a fictional world where appearances reign supreme, everything else is hidden. Not just the crimes of the past, the sins of the former self, but the substance of domestic objects - everything seems to have receded from consciousness.

But does such a starkly negative position leave anything at all to be salvaged? What distinguishes Haneke the polemicist from the artist-misanthrope, his criticism from a largely unhelpful cynicism? Perhaps part of the answer lies in his audacity to espouse a philosophy of filmmaking and art long since judged to be obsolescent and irrelevant by the non-committal postmodernist echelon of aesthetic trend mongers. Haneke openly subscribes to a kind of cinematic modernism that many pundits in the literature and visual art camps found to be outmoded even at the time (the late 1950s and early 1960s). Existential, contemplative, ambiguous, and psychologically complex, the modernism of figures like Bergman, Antonioni, Bresson, Resnais and Bertolucci (to name a few of the 
usual suspects, some of whom count among Haneke's most important influences) - may seem turgid and even somehow formulaic to audiences weaned on the work of a master collagist like Tarantino or on the shock tactics of a Noé or von Trier. Yet Haneke's poetics of negation marks the confluence of many of the values of cinematic modernism, on the one hand and, on the other, what is inarguably the most ethically perceptive and politically sincere response from the film establishment to the global transformations that have taken place since 9/11. Haneke, Sharrett points out, evades "the snide humor, affectlessness, preoccupation with pop culture, film allusions and moral blankness of postmodern art" (Sharrett 2004). Caché and the films which precede it are exemplary of an aesthetic that not only spurns psychologizing but also all the visually boisterous bric-a-brac and stylistic histrionics which tend to define much of postmillennial cinema.

\section{Conclusion: Toward a Philosophy of Inhumanism}

While owing something to the films of Antonioni and Tarkovsky, as well as evincing a philosophical and formal kinship with Angelopoulos (whose sobriquet "the last modernist" could apply equally well to Haneke), ${ }^{7}$ the sensibility of this filmmaker's glacial lens is strangely reminiscent of the radical ethics adopted by the poet Robinson Jeffers in his collection The Double Axe and Other Poems (1948). Deplored even by its own publisher, the book incensed the literary world with its pessimistic portrayal of civilization and its shortcomings and introduced the persona of the inhumanist to its unsuspecting audience. In the preface, the author notes that inhumanism denotes "a certain philosophical attitude" the tenet of which is "a shifting of emphasis and significance from man to not-man; the rejection of human solipsism and recognition of the transhuman magnificence" (Jeffers 1977: xxi). The politics of decentering which animates The Double Axe develops a morality that finds a particular resonance in Haneke's work, concerned as it is both with a dysfunctional social order and the ethical demise of the Western bourgeoisie. Moreover, the gradual erosion of the viewers' empathy with the main protagonists ${ }^{8}$ - effectively buttressed by the icy detachment of the film's style - suggests the workings of a psychology not unlike the inhumanism of Jeffers's poems. It's not that Haneke struggles to exceed the limitations of historical subjectivity in order miraculously to regain an illusory transcendental position that was never actually obtainable in the first place, but rather that he - from within that experientially constrained vantage point tries to carve out a new ethical space which necessitates precisely an awareness of the convergence of privilege and complicity. George in Caché refuses this insight, as in the scene where he is accosted by Majid's son and self-righteously rants at him:

You're sick. You're as sick as your father. I don't know what dumb obsession he fed you but I'll tell you this. You'll never give me a bad conscience about your father's sad or wrecked life. I'm, not to blame! Do you get that? If ever you try to hurt me or my family, you'll regret it.

If the crucial question that Caché brings up involves the problem of what the image wants, to paraphrase the title of Mitchell's book, it is one poorly grasped by George, who remains defensive and dishonest throughout. Although the appearance of the videotapes, Majid's suicide, and the confrontation with his son may cause him to experience guilt, the last thing on his mind is the assertion of responsibility for his own past behavior and the role he played in shaping the course of Majid's life. This contradic- 
tion, or repression, recalls the flummoxed reactions in the West to the events of 9/11, as disbelief hastily turned into a war on terror and causing an upsurge of xenophobia in the process. ${ }^{9}$ In this respect, Caché can be considered as much a parable on the psychological mechanisms responsible for the new world order as a philosophical treatise about the widening epistemic gap between seeing and perception.

What unites these two thematic emphases - the political and the philosophical - is the overarching problematization of visuality and the semiotics of the image, a focus which makes Caché not just an art house thriller but an instance of cine-thinking in the Deleuzian sense. ${ }^{10}$ The film orchestrates a discourse among myriad visual media - film, videotape, television, pictures - that to some extent permeates human experience and consciousness on every level. Caché's take on visuality is not quite that of the Heideggerian world-picture or Debord's spectacle, but it does suggest something hardly more reassuring. In the film, the image has become a feral, elusive organism; one that has turned the media of surveillance against its users, that has taken on a life of its own (although nobody is paying attention, the television in the Laurent home keeps on flashing footage of violence in Iraq and the Middle East), and that - most importantly - is eminently capable of implicating the viewer in the cosmologies of denial and guilt which these performative gestures of confrontation generate. The optical ambivalence at the film's core distresses an audience raised on the abundant distractions of mainstream cinema that Haneke's body of work is explicitly a reaction against (Porton 2005: 50). ${ }^{11}$ "The film also questions whether the image transmits meaning," the director says with reference to Code Unknown, "[e]veryone assumes it does" (Sharrett 2004). It is by asking the theoretical question "what is an image and what does it want?" that Haneke's cinema of intrusion is able to arrive at a hard-won realization of the political limitations of the traditional humanist project for the most urgent present-day concerns.

Ultimately, what is "hidden" in Caché is the memory of an historical event that the culture at large seems unprepared to acknowledge and take responsibility for. Accepting that spectacle does not represent the most suitable form in which to examine the reality of collective repression, Haneke instead opts to explore the aftereffects of this event by focusing on the capacity of the image to generate both reflection and guilt. In this film, it is the gaze itself that acts as the intruder, and its threat portentously extends to the viewer as well. In a sense, then, the audience in fact becomes the true subject of the film. By implicating the viewers in the colonialist allegory that the film constructs, and - no less significantly - by saying goodbye to the aesthetic ideology of cinematic pleasure, Caché divulges a close affinity with the kind of negative poetics associated with many modernist movements in the first half of the $20^{\text {th }}$ century. In an age when most of the images that enfold us seem dangerously seductive, those of Haneke self-reflexively question their own predilection for trickery and domination by never failing to make the viewer deeply conflicted about watching them.

\section{Notes}

1. Words spoken by the character of Majid in Caché shortly before he slashes his throat.

2. For a further discussion of the modernist leanings in Haneke, see Brigitte Peucker's The Material Image: Art and the Real in Film (2007). Peucker sees in Haneke's apsychological style a consolidation of the modernist tradition, which, she claims, the director draws upon to parody and subvert the theatricality of the bourgeois melodrama that almost always constitutes the subject matter for his films. According to Peucker, Haneke's cinema is indebted to modernist precursors such as James Joyce, Jean-Marie Straub and Danièle Huillet, Alban Berg, Franz Kafka, Arnold Schönberg and Adolf Loos (2007: 131). 
3. The October executions took place within the context of the Algerian War of Independence (19541962), and the decision to set up a curfew was the result of repeated strikes against the Parisian police by the National Liberation Front in the months preceding the massacre.

4. The 1961 massacre was also the subject of Alain Tasma's 2005 made-for-television movie Nuit noire, 17 octobre 1961, and Philippe Faucon's film about the Algerian War, La Trahison, was released the same year.

5. Skepticism regarding the referential authenticity of the image is not something which arose only in the era of digital photography. In no small part informed by the crisis of Cartesian perspectivalism that the invention of the camera merely reinforced, modernism in the visual arts frequently gravitated toward an interrogation of the epistemological trustworthiness of the image. This is also an obsession which fuels Blow-Up (1966), directed by Antonioni, one of Haneke's most beloved auteurs.

6. My argument here departs somewhat from Mitchell's use of the term, which could be construed as intimately related to his notion of metapictorialism, a capacity that he seems to imply that all images might possess in principle.

7. Angelopoulos is a filmmaker who also shares Haneke's interest in issues of immigration, globalization, and the sociology of a changing Europe.

8. For a longer discussion of the permutations of empathy in Caché, see Gibson 2006.

9. As Gibson has shown, the word "terror" or inflections thereof occurs with astounding regularity in the vocabulary of the Laurents. According to his interpretation, the film suggests that the protection of "white bourgeois privilege" is what really fuels the war on terror. See Gibson 2006: 36.

10. An idea first developed in Deleuze's two mid-80s film books The Movement-Image (1983) and The Time-Image (1985), the notion of filmic thought has subsequently been explored in an ever growing selection of scholarly works. It most generally involves the presupposition that films are capable of doing philosophy and should be seen as a kind of manifestation of thought in action, graspable but ultimately unparaphraseable by language. See for instance Alliez 2000; Mulhall 2002: On Film, and, more recently, Frampton 2006. See also Deleuze 1986; 1989.

11. For an analysis of the ways in which Haneke's oeuvre relates to "the distractions of visual culture," see Wynter 2006.

\section{Bibliography}

Adorno, T.W. and Horkheimer, M. (1944, 1972) Dialectic of Enlightenment. New York: Continuum.

Alliez, E. (2000) 'Midday, Midnight: The Emergence of Cine-Thinking,' Trans. Dailey, P., in Flaxman, G. (ed.) The Brain is the Screen: Deleuze and the Philosophy of Cinema. Minneapolis: U of Minnesota P, 93-30.

Clark, T.J. (2006) The Sight of Death; An Experiment in Art Writing. New Haven: Yale University Press.

Debord, G. (1967) La société du spectacle. Paris: Buchet/Chastel.

Debray, R. (1996) Media Manifestoes: On the Technological Transmission of Cultural Forms. Trans. Rauth, E. London: Verso.

Deleuze, G. (1983; 1986) Cinema 1: The Movement-Image. Trans. Tomlinson, H. and Habberjam, B. London: The Athlone Press.

Deleuze, G. (1985; 1989) Cinema 2: The Time-Image. Trans. Tomlinson, H. and Galeta, R. Minneapolis: U of Minnesota P.

Eisenstein, S. (1998) 'The Problem of the Materialist Approach to Form,' in Taylor, R. (ed.) The Eisenstein Reader. London: BFI.

Frampton, D. (2006) Filmosophy. London: Wallflower Press.

Gibson, B. (2006) 'Bearing Witness: The Dardenne Brothers' and Michael Haneke's Implication of the Viewer,' Cineaction 70: 24-38.

Haneke, M. (1992) 'Film als Katharsis,' in Bono, F. (ed.) Austria (In) Felix: Zum Österreichischen Film der 80er Jahre. Graz: Edition Blimp/Rome: Aiace.

James, N. (2007) 'The Films of 2006', Sight and Sound 17 (1): 32-35.

Jameson, F. (1991) Postmodernism, or, the Cultural Logic of Late Capitalism. London: Verso.

Jeffers, R. (1948; 1977) The Double Axe and Other Poems. Foreword William Everson. Afterword Bill Hotchkiss. New York: Liveright.

Mitchell, W.J.T. (2002) 'Showing Seeing: A Critique of Visual Culture”, Journal of Visual Culture 1 (2): 165-181.

Mitchell, W.J.T. (2005) What Do Pictures Want? The Lives and Loves of Images. Chicago: University of Chicago Press.

Mulhall, S. (2002) On Film. London: Routledge. 
Nietzsche, F. (1956) The Birth of Tragedy and The Genealogy of Morals. Trans. Golffing, F. New York: Anchor Books.

Peucker, B. (2007) The Material Image: Art and the Real in Film. Stanford: Stanford University Press.

Porton, R. (2005) 'Collective Guilt and Individual Responsibility: an Interview with Michael Haneke', Cineaste 31 (1): 50-51.

Sharrett, C. (2004) 'The World that is known: Michael Haneke interviewed', Kinoeye: New Perspectives on European Film 4 (1): par. 18. http://www.kinoeye.org/04/01/interview01.php

Sharrett, C. (2005) Review of Caché. Cineaste 31 (1): 60-62. Shaviro, S. (1993) The Cinematic Body, Minneapolis: University of Minnesota Press.

Taylor, C. R. (1998) The Mask of Art: Breaking the Aesthetic Contract - Film and Literature. Bloomington: Indiana University Press.

Wheatley, C. (2006) 'Secrets, Lies and Videotape', Sight and Sound 16 (2): 32-36.

Williams, L. (2004) 'Porn Studies: Proliferating Pornographies On/Scene: An Introduction,' in Williams, L. (ed.) Porn Studies. Durham: Duke University Press.

Wynter, K. (2006) 'Excesses of Millennial Capitalism, Excesses of Violence: Several Critical Fragments Regarding the Cinema of Michael Haneke', Cineaction 70: 39-45.

ASBJøRN GRøNSTAD, Dr.Art., Professor, Department of Media, Culture and Social Science, University of Stavanger, Kristine Bonnevies vei 30, NO-4068 Stavanger, asbjorn.gronstad@uis.no 